\section{"Engage and attract me, then I'll share you": an analysis of the impact of post category on viral marketing in a social networking site}

\author{
Marcos Inácio Severo de Almeida \\ Milena Costa \\ Ricardo Limongi França Coelho \\ Paulo Roberto Scalco
}

Federal University of Goiás, Faculty of Management, Accounting and Economics, Goiânia, Goiás, Brazil
Received on

07/22/2015

Approved on

08/30/2016

Responsible editor:

Prof. Dr. Guilherme de Farias

Shiraishi

Evaluation process:

Double Blind Review

\begin{abstract}
Purpose - The purpose of this paper is to analyze the impact of different types of content of viral marketing in a popular social networking site. Our research is founded on recent studies which categorize posts on Facebook.
\end{abstract}

Design/methodology/approach - Data for 2583 posts in eight profiles of Brazilian beer brands were coded and analyzed. We used a regression model and Analysis of Variance to establish relationships among independent variables and a dependent variable.

Findings - Two hypotheses were supported. There was a positive relationship between posts of the categories Fan and Promotion and Publicity and viral marketing. Posts of the categories Information and Pool did not have any significant effects, and confirmed previous studies which analyzed likes and comments as dependent variables.

Originality/value - Previous studies using the platform did not categorize posts created by brand fans/followers. Our typology is a quantitative improvement in relation to studies with similar objectives. Hence, marketers involved with brand management on Facebook should publish posts which promote the brand and reproduce content generated by people engaged with it if they seek to increase the viralization capacity of such posts.

Keywords - Social media marketing; social media metrics; social networking sites; viral communications; viral marketing.

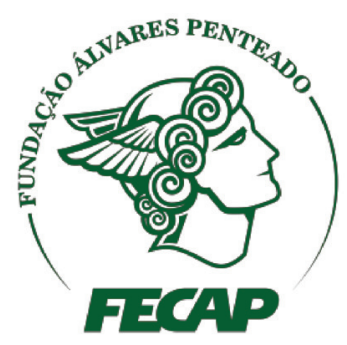

Review of Business Management

DOI: $10.7819 /$ rbgn.v18i62.2620 


\section{Introduction}

Ever since it was used to classify the successful marketing action of a company providing free email service (Jurvetson \& Draper, 1997), the term 'viral marketing' has become popular and has been circulated among managers anxious to disseminate the most diverse content to their markets. This triggered the efforts of researchers to understand the dynamics of the functioning of viral marketing and people's interaction with online content produced by brands. At present, much of the contact between brands and their consumers occurs in interactive online environments in which managers use viral content as a means of extending the reach of campaigns (Nelson-Field, Riebe, \& Newstead, 2013). This reach usually refers to both economic response variables such as sales, and non-economic variables, such as dissemination of information and creation of awareness (Hinz, Skiera, Barrot, \& Becker, 2011).

Although viral marketing research has been in existence for almost two decades, there is a lack of empirical effort to explain the effectiveness of viral content (Lindgreen, Doeble, \& Vanhamme, 2013). Much of this content is published in social media because viral marketing uses a pre-existing social network to spread marketing information via word-of-mouth (WOM) among users of that social network (Yang, Yao, Ma, \& Chen, 2010). As a result, research conducted with the help of data from virtual social networks is becoming increasingly common (Cvijikj \& Michahelles, 2013; De Vries, Gensler, \& Leeflang, 2012; Groeger \& Buttle, 2014; Kim, Spiller, \& Hettche, 2015; Ransbotham, Kane, \& Lurie, 2012; Sabate, Berbegal-Mirabent, Cañabate, \& Lebherz, 2014; Schulze, Schöler, \& Skiera, 2014; Smith, Fischer, \& Yongjian, 2012; Swani, Milne, \& Brown, 2013), although authors stress that organizations have not yet been able to measure the effectiveness of strategies based on these environments (Hoffman \& Novak, 2012; Kumar, Bhaskaran, Mirchandani, \& Shah, 2013).
Virtual social networks are perfect platforms for viral marketing as they make it possible for people to connect on the basis of broad specialized relationship links, through virtual communities (Boyd \& Ellison, 2007). Here, individuals spontaneously reproduce content sponsored by brands which, like a virus, avail of the virtual social network's capacity to multiply (Vilpponen, Winter, \& Sundqvist, 2006). Literature about content sharing is recent and robust enough to explain social and psychological factors that influence this behavior on social media. Oh and Syn (2015) categorized 10 motivational factors responsible for exerting pressure on information sharing. On Facebook, the most popular social networking site, they had identified that social engagement, learning and altruism are the main drivers of this behavior.

A different stream of empirical efforts concentrates on social media characteristics that are responsible for facilitating content sharing. The social affordances of the platform may enhance user involvement that can lead to spreading behavior (Oeldorf-Hirsch \& Sundar, 2015). However, an important gap remains and refers to which marketing-content characteristics can lead to sharing. Our article contributes to building knowledge about this topic by presenting a research which set out to identify the effect of different types of content on its dissemination. It is an investigation based on studies which categorize marketing-oriented content in virtual social networks applied to the reality of interaction between brands and target audiences in these environments. Research on viral marketing has produced consistent results, especially with respect to probabilistic models of reach or the structure of message dissemination (De Bruyn \& Lilien, 2008; Iribarren \& Moro, 2011; Van der Lans, Van Bruggen, Eliashberg, \& Wierenga, 2010; Yang et al., 2010), but has not yet been fully able to: i) identify the characteristics of the message spread by users; or ii) explain the power of such characteristics in sharing the message.

This focus led us to categorize 2583 posts on the profiles of eight brands of Brazilian beer 
on Facebook over a period of three months. In operational terms, this social network was chosen because of how representative it is of daily individual Internet activities, with over a billion active users per month, $81.7 \%$ of whom are located outside North America (Facebook, 2014). They interact directly with companies and brands which create pages and use this environment as a tool for contacting their clients in order to spread advertising campaigns (Boyd \& Ellison, 2007; Smith et al., 2012). In theoretical and empirical terms, this choice was made because, on Facebook, users can spontaneously share the content published in company or brand profiles in their own pages (Zarrella \& Zarrella, 2010). Our approach is an important initiative of analyzing viral marketing, as similar studies based on this virtual social network only focus on the options of likes and comments as dependent variables (De Vries et al., 2012; Swani et al., 2013).

Subsequent sections present viral marketing as a marketing action, discuss the categorization of content in virtual social networks and present the conceptual framework and hypotheses of the study, based on theoretical assumptions which consider the effectiveness of online content according to technical features, functions and propagandistic appeal. The following sections discuss the method and results, and are followed by a discussion of the study's main limitations and its theoretical and managerial implications.

\section{The State of research on viral marketing}

\section{I The fundamental characteristics of empirical studies on viral marketing}

The term viral marketing describes any strategy which encourages individuals to spread a marketing message on these networks, thereby creating potential for exponential growth in the exposure and influence of this message (Camarero \& San José, 2011). Research on viral marketing focuses on two distinct phenomena: i) the production of marketing content and design of a reproduction strategy for that content; and ii) spontaneous dissemination of the message through electronic WOM, often without control over the nature or content of that message (Swanepoel, Lye, \& Rugimbana, 2009). As stated by Camarero and San Jose (2011), there is no clear definition of the meaning of viral marketing: there is no consensus on whether it is a marketing action controlled, sponsored and triggered by a certain company or a mere informal process of dissemination and repetition of content carried out by individuals. Much of this divergence occurs because viral marketing is a management-marketing application of the WOM phenomenon (Modzelewksi, 2000) in which companies and brands rely on electronic WOM as a tool to disseminate campaigns (Hennig-Thurau, Gwinner, Walsh, \& Gremler, 2004).

The origins of viral marketing are directly related to WOM communication, although they occur exclusively in virtual environments (Camarero \& San José, 2011). Since the messages are not requested by the recipient, they can be ignored. This means that content coming from close reliable sources is more likely to be accepted than others from unknown sources. The latter are classified as less valuable and more risky information thus being discarded (De Bruyn $\&$ Lilien, 2008). In terms of research conducted on this subject, investigations alternate between the investigation by analyzing electronic WOM communication through individual data, and the investigation that focuses on the strategy or form of dissemination of content. Table 1 classifies the theoretical and empirical quantitative research on viral marketing into four groups, highlights the main characteristics of each, and presents the dependent variable usually attributed in these studies. Exclusively theoretical or qualitative studies were excluded from this survey for reasons of suitability to its purpose. 
Table 1

Main characteristics of studies on viral marketing

\begin{tabular}{lll}
\hline Characteristics & Dependent variable & Main studies \\
\hline Group 1 & & \\
Analyses of electronic WOM communication in & Reach; Frequency; Adoption risk. & Aral and Walker (2011); Groeger and \\
blogs and microblogs, such as Twitter, and virtual & & Buttle (2014); Jansen, Zhang, Sobel, \\
social networks, such as Facebook, performed & & \& Chowdury (2009); Nelson-Field \\
by analyzing interaction between brands and & et al. (2013); Schulze, Schöler, L., \& \\
individuals. In certain cases, such studies involve & & Skiera (2014). \\
analysis of the sharing of applications or media, & & \\
such as video or a game, for example. &
\end{tabular}

\section{Group 2}

Correlational and experimental studies investigating electronic WOM communication by means of latent variables supported by methods based on questionnaires, with samples of different contexts, such as college and undergraduate students and young adults, applied to different digital platforms.

Electronic WOM intention; Forwarding online content; Frequency of sending; Frequency of visits to digital platforms; Number of comments written on opinion platforms; Opinion leadership; Opinion giving; Opinion passing; Opinion seeking; Probability of forwarding.
Camarero and San José (2011); Chu and Kim (2011); Eckler and Bolls (2011); Harvey, Stewart, \& Ewing (2011); Hennig-Thurau et al. (2004); Ho and Dempsey (2010); Sohn (2009); Southgate, Westoby, \& Page (2010); Sun, Youn, Wu, \& Kuntaraporn, (2006).

\section{Group 3}

Studies which analyze the effects of reviews and individual incentive strategies for practicing electronic WOM in environments such as information-sharing services (Yahoo!Movies) and online retailer services, such as Amazon.com.
Purchases based on recommendations; Number of recommendations sent; Number of online reviews; Placing of a certain product on the sales ranking; Reasons for the success of recommendations; Sales volume.
Ahrens, Coyle, \& Strahilevitz (2013); Chevalier and Mayzlin (2006); Duan, Gu, \& Whinston (2008); Zhang, Ma, \& Cartwright (2013)

\section{Group 4}

Research focusing on the analysis and proposal of analytical models and message propagation dynamics, by means of theoretical structures based on social networks and applied to e-mail, instant

Reach; Propagation; Average number of users reached by a particular message; Number of recommendations.
Bampo, Ewing, Mather, Stewart, \& Wallace (2008); De Bruyn and Lilien (2008); Hinz et al. (2011); Iribarren and Moro (2011); Leskovec, Adamic, \& Huberman (2007); Van der Lans et al. (2010); Yang et al. (2010).

\subsection{Integrating viral marketing research into social media engagement literature}

Table 1 is more comprehensive than the surveys conducted by either Nelson-Field et al. (2013) or Vilpponen et al. (2006). This classification into four groups supports the results found in the literature review of Chan and Ngai (2011), which identified a dissemination of research on the topic. In addition, it exposes the fragility of defining the terms electronic WOM communication and viral marketing (Camarero \& San José, 2011), and thereby shows the difficulty of delimiting a widespread phenomenon of interaction between consumer and company in digital platforms. Group 1, in particular, is of special interest to our research as it includes a smaller number of studies and provides an opportunity for research in the context of virtual social networks, such as Facebook.

Nevertheless, it is substantial to fill the gap presented in Group 1 regarding the literature about brand engagement in social media. According to Brodie, Hollebeek, Jurić and Illić (2011) the conceptual domain of customer engagement lies on interactive experience and value co-creation within marketing relationships. This concept evolved to the investigation of consumer brand engagement in social media, defined as a "consumer's positive valence brandrelated cognitive, emotional and behavioral activity during or related to focal consumer/brand 
interactions" (Hollebeek, Glynn, \& Brodie, 2014, p. 154). The relationship assumption behind the concept becomes more intense in virtual contexts (Dessart, Veloutsou, \& Morgan-Thomas, 2015) where firms and individuals are directly connected.

Brand-related interactions occur at different levels where the main objective is to encourage and increase engagement (Azar, Machado, Vacas-de-Carvalho, \& Mendes, 2016). Brand content acts as a marketing instrument to provoke response on awareness metrics such as likes, comments and shares. The primary objective to brands is to build reach across these levels (Peters, Chen, Kaplan, Ognibeni, \& Pauwels, 2013). Specifically, sharing behavior is an important phenomenon on social networks and should be scrutinized by marketers and researchers to evaluate brand engagement as it reflects positive attitudes toward a brand (Hoffman \& Fodor, 2010).

Considering the conceptual definition of customer engagement proposed by Brodie et al. (2011) and its evolution to social media environments introduced by Hollebeek et al. (2014), we can offer a valuable research insight about how this phenomenon should be tackled to unveil viral marketing in social networks. Our approach resorts on how different brand content is produced and disseminated, in order to trigger awareness and reach on preexisting networks built by individuals. Hence, brand engagement is defined in a behavioral dimension, since it reflects viral marketing activity of brand content in virtual social networks.

\section{Brand content categorization in virtual social networks}

Virtual social networks are groups of individuals with common interests in which the basic principle is that the structure of social relationships is crucial to the content of these relationships (Wellman, 2001). They are changing the ways in which companies interact with their customers by means of actions which include recommendations from contacts and friends, content disseminated and generated by users and assessments of products and services (Rohm, Kaltcheva, \& Milne, 2013). Such actions are at the center of individual engagement and interaction between customer and brand, since consumers can share recommendations for purchases or information related to companies or brands before, during and after the moment of purchase (Rohm et al., 2013; Schultz \& Peltier, 2013). Professionals in the advertising market perceived the power of virtual social networks to support the production of advertisements and targeted advertising (Hoy \& Milne, 2010). However, one challenge for the integration of these networks is the difficulty in quantifying the return on activities, since companies and brands have not yet consolidated metrics that could provide information as to whether the content posted in these environments has economic or non-economic effects (Hinz et al., 2011).

Created in 2004 for student purposes, Facebook is a virtual social network that somehow moved away from its initial proposal. It is a digital platform that allows users to create profiles containing personal information, interests, photographs and invite other users (Smith et al., 2012). In addition to individuals, companies and brands can also create profiles, which are used as a tool to approach their clients in order to disseminate advertising campaigns (Boyd \& Ellison, 2007; Smith et al., 2012). Abram and Pearlman (2008) present at least two reasons why a company should keep a Facebook page: first, it offers marketers an excellent mechanism for brand building because of its ability to viralize messages and content; secondly, it enables companies to communicate with consumers through interactive actions. Of the interaction alternatives, the virtual social network, in particular, provides the option of sharing so that individuals can spontaneously reproduce content posted by third parties so that their friends can view such content. This consensual reproduction sparks the interest of researchers studying the dynamics of viral 
marketing, since the share option is considered by authors such as Peters et al. (2013) as one of the outputs of brand management in these environments.

The research and conceptual frameworks for characterizing content published on digital platforms are very diverse. In Facebook specifically posts are one of the items analyzed by researchers. In these cases, studies focus on features of design (interactivity with the user, number of media and text elements, size of post and vividness) and on content - entertainment, both emotional and informational (De Vries et al., 2012; Rauschnabel, Praxmarer, \& Ivens, 2012; Swani et al., 2013). The most striking characteristic of the studies which analyze sharing as the dependent variable is that they usually do not attach it to viral marketing. They usually refer to it as consumer engagement (Cvijikj \& Michahelles, 2013) or response (Kim et al., 2015) because the association of sharing with two other actions in the social network: comment and liking.

All this research indicates advances in understanding the types of posting on Facebook, although it is admitted that more could be known about the impact they have on sharing, a metric related to viral marketing. Of the studies which categorize posts on Facebook, the grand majority focuses on likes and comments as dependent variables (De Vries et al., 2012; Sabate et al., 2014; Swani et al., 2013). The ones which defined sharing as dependent variable (Kim et al., 2015) did not concentrate on analyzing it as a form of viral marketing. Content which is popular and relevant for users is positively associated with brand loyalty in virtual social networks (Erdoğmuş \& Çiçek, 2012), since studies indicate that such content can foster engagement with customers and produce managerial results, such as sales (Smith et al., 2012).

\section{Conceptual framework and hypotheses}

\section{I Framework overview}

Our conceptual framework is based on the construction of seven hypotheses referring to post categories which might be used during interaction between a brand and its target audience in a virtual social network. Marketers are increasingly including systems such as Facebook in their strategies, especially after evidences that virtual branding actions could raise the levels of the return on investment (Kumar \& Mirchandani, 2012). Our model is based on the argument of Swanepoel et al. (2009) that viral messages bring together verbal and visual stimuli. This is why we consider the classification of post typology and propose the measurement of this content on a viral marketing measure (sharing).

Our approach considers brand activity on Facebook, which may include applications, present surveys, incorporate images and videos, and reproduce informative, promotional/ advertising content or ones that are generated by users. These activities refer to the brandrelated interactions described by the literature about brand engagement on social media, where an interactive experience between individuals and brands (Hollebeek et al., 2014) occurs. One behavior resulting from this dynamics is post sharing, when individuals spontaneously reproduce brand content to their friends and personal contacts.

These assumptions led to the creation of seven categories, a number larger and more comprehensive than in previous studies. The underlying logic is that different typologies may produce different variability on viral marketing. Posting types were created after reviewing extant research which: i) analyzed the effectiveness of online banners because of their similarity with brand posts, as both have factors which could induce people to interact (De Vries et al., 2012; Fennis \& Stroebe, 2010); and ii) classified posts or viral advertisements according to technical features, function and propagandistic appeal (Eckler \& Bolls, 2011; Porter \& Golan, 2006; Rauschnabel et al., 2012). Figure 1 summarizes the conceptual framework, which contains the hypotheses in which the response variable is viral marketing, operationally defined as the option "share" on Facebook. 


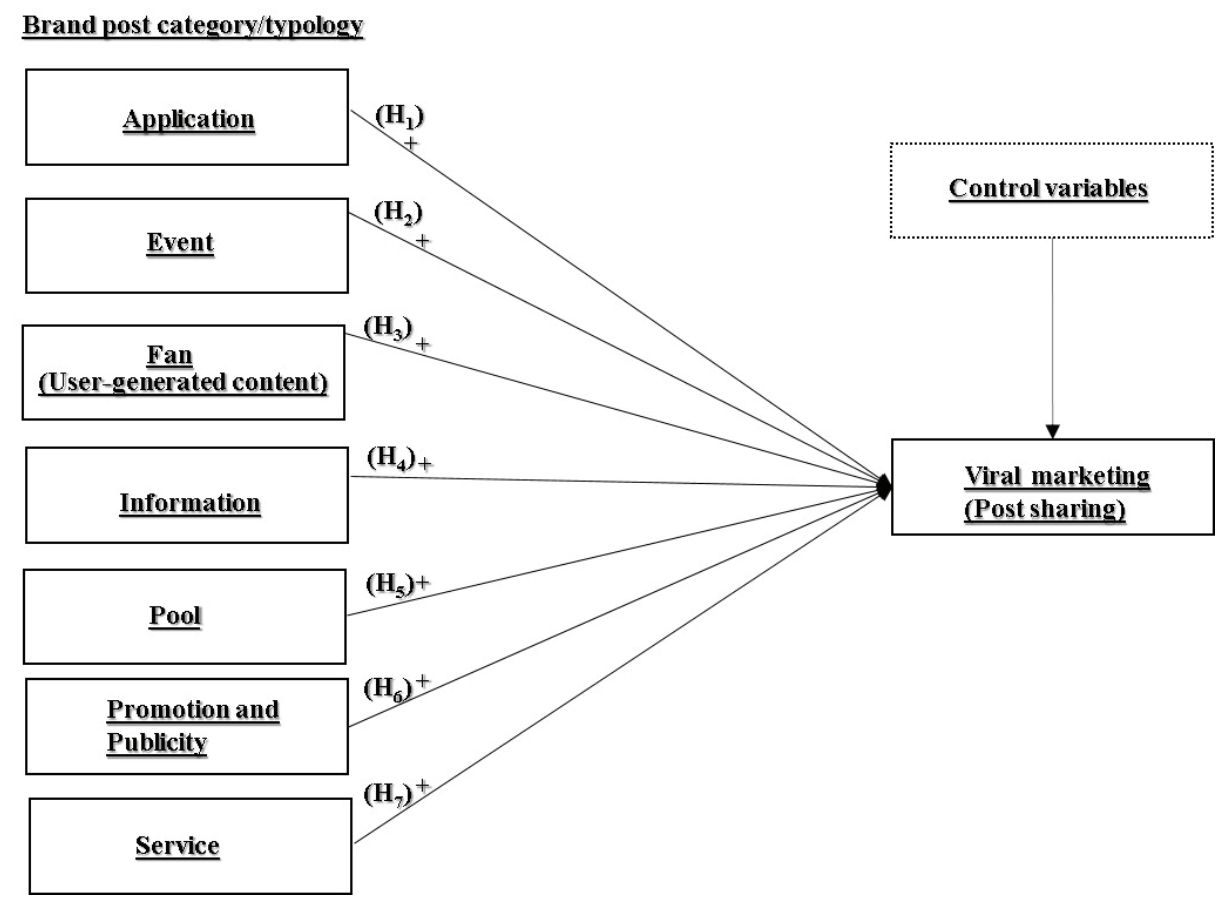

Figure 1. Conceptual framework and expected signals of hypothesis testing

\subsection{Hypotheses development}

This section presents the hypotheses construction, founded on brand activity on Facebook. It incorporates social media engagement in the form of post sharing, as expressed in Figure 1. This behavioral activity on Facebook corresponds to a spontaneous dissemination of the message through electronic WOM, a specific form of viral marketing (Swanepoel et al., 2009). The seven hypotheses refer to activities available for marketers to engage their target audience in a social media environment: the development of applications, event announcements, publishing user-generated content (fans), dissemination of information, pool announcements, brand promotion and publicity, and service offering. Table 2 summarizes hypotheses development.

Applications became part of the Facebook platform in May 2007. Consequently, third parties could develop the most diverse software and add a dimension of use not covered by the core components of the virtual social network (Claussen, Kretschmer, \& Mayrhofer, 2013).
Russell-Bennett and Neale (2009) state that applications are an alternative to brand promotion, since one of the goals of their developers is that users share them with their contacts. Research on the use and dissemination of applications is still in its early stages, although it is already possible to infer that their use (Eling, Krasnova, Widjaja, \& Bruxmann, 2013) and the sharing of applications provided by brands are influenced by recommendations from friends.

H1: Brand posts categorized as Application have a linear and positive effect on post sharing

Facebook offers the option to announce events so that managers can promote them for consumers (Lee $\&$ Paris, 2013). For marketers, the fundamental question is to discover how people perceive such marketing actions (Lee, Xiong, \& $\mathrm{Hu}, 2012)$. Events normally appeal to feelings and emotions (Martensen \& Gronholdt, 2008) and, once a company or brand in virtual social 
networks mentions them, they can attract the special attention of the target audience. Lee et al. (2012) confirmed the hypothesis that user attitude in an event page exerts a positive impact on the intention of this user to attend the event. This result suggests that the relationship between brand posts of this nature and post sharing is positive.

H2: Brand posts categorized as Event have a linear and positive effect on post sharing

Accordingly, user-generated content, created outside of professional routine and practice, is individually or collectively produced and can be modified, consumed and shared (Kaplan \& Haenlein, 2010). User-generated brand content varies between the different virtual social networks (Smith et al., 2012), but one of its main features is its ability to serve as a credible source of information for other users (Pavlou \& Dimoka, 2006). On Facebook specifically, it is produced by the user, although the brand or company can post it. The study by Goh, Heng, and Lin (2013) helps to understand the economic behavior resulting from such content, but there is scope for further research to investigate the impact of content of this nature on non-economic variables, such as sharing.

H3: Brand posts categorized as Fan have a linear and positive effect on post sharing

Dholakia, Bagozzi, and Pearo (2004) argue that information seeking is an important reason why people use social networks and participate in virtual communities. It is not clear if such participation directly influences interaction between individuals and brands. Taylor, Lewin, and Strutton (2011) found a weak, yet positive, relationship between information content and individual attitudes to advertisements posted on social networks. Similarly, from a sample of 402 subjects, Lin and Lu (2011) showed that Facebook users believe that the use of a social network improves efficiency through sharing information with others. On the other hand, in the study by De Vries et al. (2012), the hypothesis that informative posts influence likes and comments was not supported. These results are diverse from the ones founded by Cvijikj and Michaehelles (2013), where informational posts positively influence likes and comments, but do not exert influence on sharing. Given this divergence of results, we chose to consider a positive influence by posts from this category.

\section{H4: Brand posts categorized as Information have a linear and positive effect on post sharing}

Another key feature in social media is interactivity, as feedback mechanisms in real-time enable users to modify the content structure of the original message (Hoffman \& Novak, 1996). Such a feature stimulates consumer engagement at different levels, ranging from participation through superficial action to commitment to the co-creation of content (Hennig-Thurau et al., 2010). One way of participating is through surveys in which individuals respond to questions in virtual social networks. Moderated levels of interactivity indirectly influence engagement with advertisements based on the web (Fortin \& Dholakia, 2005), while high levels of interactivity are negatively related to likes and positively related to comments (De Vries et al., 2012). Accordingly, Cvijikj and Michahelles (2013) found a positive relationship between posts in the form of sweepstakes (a form of interactivity) in brand pages and post comments, but no effect on its sharing. Since the effects of this category are conflicting and partially supported in the literature about virtual social networks, the same procedure for the construction of the previous hypothesis is adopted for this case.

H5: Brand posts categorized as Pool have a linear and positive effect on post sharing 
Companies spend a considerable part of their marketing budgets on sales promotion, which could have direct effects or go beyond an immediate influence on sales (Heerde \& Neslin, 2008). Promotions are crucial for informing consumers about the availability of a product or for creating public awareness of marketing activities (Bagozzi, 1998). In the context of online shopping, retailers include sales promotions, such as discounts and giveaways, to attract buyers to their websites, as there is evidence in the literature that promotions are positively associated with perceived value (Park \& Lennon, 2009). In the context of Facebook, De Vries et al. (2012) found a positive relationship between a post announcing contests and the number of likes received for that post.

In the field of Integrated Marketing Communication (IMC), advertising somewhat accompanies promotional practices. It is recognized as an efficient way of communicating between company and consumer (Stammerjohan, Wood, Chang, \& Thorson, 2005). Although advertising guarantees space in the media for promoting a brand, there is always the inherent risk of it being something that marketing managers cannot control (Eisend \& Küster, 2011). In the digital context, the advertising construct receives new contributions as it is directly related to: i) content with fun and entertainment; and ii) the interactivity characteristic of this media. Taylor, Strutton and Thompson (2012) concluded that entertainment features have positive effects on the sharing of ads, while Lin and Peña (2011) showed that in Twitter posts with emotional content have a greater influence on the sharing of users. This type of post has been named Promotion and Publicity as it includes actions related to advertising or brand promotion in the virtual social network. This will be treated in greater detail in the Method section. It is expected that such posts will have a positive effect on sharing.

\section{H6: Brand posts categorized as Promotion and Publicity have a linear and positive effect on post sharing}

Information seeking is one of the four main reasons why users participate in Facebook groups (Park, Kee, \& Valenzuela, 2009). However, this information could concern the informative content of the brand (De Vries et al., 2012), or could mention an additional service being offered, such as details about virtual retail shopping or customer service. The literature which classifies posts in virtual social networks has not characterized content of this nature, therefore the impact that this type could have on viral marketing has not been measured. Identifying the existence of this impact is important since there are still divergent results for certain types of content. For example, although users believe that by using social networking they can acquire more information and improve efficiency in sharing information with others (Lin \& Lu, 2011), it was observed that informational post types do not affect likes or comments (De Vries et al., 2012). For Hypothesis 7, to specifically address the issue of information about services, we resorted to arguments of researchers who claim that additional dimensions of the service could influence service satisfaction at individual level (Raja, Bourne, Goffin, Çakkol, \& Martinez, 2013).

H7: Brand posts categorized as Service have a linear and positive effect on post sharing 
Table 2

Summary of hypotheses development

\begin{tabular}{ll}
\hline Hypothesis no. & Hypotheses \\
\hline 1 & Brand posts categorized as Application have a linear and positive effect on post sharing \\
2 & Brand posts categorized as Event have a linear and positive effect on post sharing \\
3 & Brand posts categorized as Fan have a linear and positive effect on post sharing \\
4 & Brand posts categorized as Information have a linear and positive effect on post sharing \\
5 & Brand posts categorized as Pool have a linear and positive effect on post sharing \\
6 & Brand posts categorized as Promotion and Publicity have a linear and positive effect on post sharing \\
7 & Brand posts categorized as Service have a linear and positive effect on post sharing \\
\hline
\end{tabular}

\section{Method}

This research resorts to secondary data in order to identify the impact of post typology on post sharing. This is a common empirical approach on marketing research using social network data, as shown by the studies by De Vries et al. (2012), Rohm et al. (2013), Smith et al. (2012) and others. Eight official profiles of Brazilian beer brands were selected on Facebook. We decided for this product given the high levels of consumption in the country, which denotes an important fast-moving consumer good (FMCG) to consumer behavior. Brand selection followed two criteria: (i) the brands chosen had to have effective participation in the mass market. For example, they could not be special beer brands or be exclusively regional; and (ii) the brands had to participate regularly in social networking, with a certain frequency of posts. The main objective in choosing eight different brands was to control the effect of the brand on the dependent variable, a similar procedure used by Kim et al. (2015), which controlled product category. The number of posts (2583), covering the period between December 2012 - February 2013 , is significantly greater in number than those analyzed in previous studies on Facebook (De Vries et al., 2012; Kim et al., 2015; Sabate et al., 2014; Swani et al., 2013).

\subsection{Procedures for collecting data and definition of variables}

Data were collected from the profiles of brands on just one occasion, by means of a web browser option that saved all the data from each page. With this procedure the whole content was saved, up to the point at which the page was downloaded and stored in an html file. Data for 2583 posts in eight profiles of brands were then systematized into a spreadsheet and coded. One of the authors was assigned the task of classifying all posts. This categorization of posts is broader than previous research on Facebook, and used types based on the content of the messages published. Throughout the process, the responsible author received instructions from another researcher, who at times requested a re-categorization of certain posts when divergences were observed. Categorization followed the definitions given in Table 3 and re-categorization procedure, which occurred after discussion and agreement between both researchers, was reproduced from the literature review conducted by Furrer, Thomas and Goussevskaia (2008).

Rauschnabel et al. (2012) limited their classification of posts according to technical characteristics such as size, amount of text, media elements and presence of surveys. A similar procedure was used by Sabate et al. (2014, p. 1004), who defined Facebook posts by structural 
characteristics, such as containing images, videos and links, instead "capturing the meaning of the content itself”. De Vries et al. (2012) used six types, but included characteristics other than content, such as position of the brand post on the page. Smith et al. (2012) formed six categories and made comparisons between social networks, such as Facebook, Twitter and YouTube, while Swani et al. (2013) identified three types: those which use corporate brand names, those which refer to emotional content, and those which make instantaneous references for the purchase of products or services. Cvijikj and Michahelles (2013) also classified only three types of content (entertainment, information and remuneration) while Kim et al. (2015) defined their typology using content orientation (task, interaction and self-oriented).

The classification proposed in our study is a quantitative improvement on the aforementioned studies and divides posts into seven categories: Application, Event, Fan, Information, Pool, Promotion and Publicity and Service. Table 3 describes the independent variables which are of a qualitative nature and refer to posts content. The dependent variable is the number of shares received by each post. Share is an important measure of use in virtual social networks and refers to the extent to which users exchange, distribute and receive content (Kietzmann, Silvestre, \& McCarthy, 2012). It is, therefore, a non-economic variable for disseminating information and creating brand awareness (Hinz et al., 2011). We decided to present the dependent variable in its absolute form (in level) in order to identify the marginal effect of post type on the number of shares. This choice differentiates our analyses from those of De Vries et al. (2012), Kim et al. (2015) and Sabate et al. (2014), who presented the dependent variables in logarithmic form. It is also different from the study conducted by Cvijikj and Michahelles (2013), who presented the dependent variables in the form of an index.

A group of six control variables was also considered in order to isolate the actual effect of each category on the number of shares. Firstly, the brand was controlled by collecting posts on the profiles of eight beer brands (brand1 to brand8), as in the study by De Vries et al. (2012) and Kim et al. (2015), which used product categories as a control variable. This study was also based on De Vries et al. (2012) work as it considered the time of the week when the posting occurred (mid-week or weekend) as a control variable. Four other variables were defined: (i) post duration, from the date on which the content of the profiles was saved by the researchers (duration); (ii) number of posts of that brand on that same day (quantity); (iii) time of day (morning, afternoon or evening); and (iv) the month in which posting occurred (December, January or February). This total of six control variables also exceeds previous studies in the context of Facebook.

\section{Table 3}

\section{Independent variables of the study}

\begin{tabular}{llc}
\hline Variable & Description & Notation \\
\hline Application & $\begin{array}{l}\text { A post with a direct link to an application created by the beer brand holding company, } \\
\text { whose purpose is to provide a software with specific objectives. Creating applications is a } \\
\text { tool offered by Facebook to the brands. For example, an application for monitoring all } \\
\text { carnival dance groups in a large Brazilian city. }\end{array}$ \\
\hline Event & $\begin{array}{l}\text { Posts covering the brand or event connected to the brand and which include media, such as } \\
\text { photos and videos. This category mainly contains photos and albums produced during the } \\
\end{array}$ & 2013 Brazilian Carnival and reproduced in profiles of the brands on Facebook. \\
\hline
\end{tabular}




\begin{tabular}{ll}
\hline Variable & Description \\
\hline Fan & A publication with content created by a follower/ fan. This follower is responsible for the \\
& central idea or sends the photograph which is used in the post, and their participation in \\
the reproduction of this content in the profile of the brand is always mentioned. It also \\
includes a post in which the brand stimulates the follower to contribute ideas which will be \\
transformed into a future post, without any previously announced compensation.
\end{tabular}

\subsection{Empirical model and specification tests}

An econometric model was built, where the dependent variable was the number of shares, a means of analysis of viral marketing. The model includes the quantitative and qualitative independent variables discussed above. Representations of the intercept and slope parameters are reproduced in Equation 1. It is worth noting that the equation omits reference variables, removed to facilitate the operationalization of the statistical analysis. As a general principle for the inclusion of dummy variables which indicate different groups, in the case of the regression model presenting " $\mathrm{g}$ " groups or categories, the need for the inclusion of $g-1$ variables in the models is emphasized (Wooldridge, 2013). The reference variables defined in the model were: "br1" for the beer brand, "ser" for posts in the services category, "aft" for the afternoon, "mid" for the mid-week period and "dec" for the month of December. The grouping was selected after carrying out a stepwise procedure where this combination resulted in a statistically insignificant intercept, which made it possible to make appropriate comparisons between the coefficients associated to the groups of dummy variables and the basegroup intercept (Wooldridge, 2013). In short, the statistical insignificance of the constant enabled comparisons between the coefficients of the types of post when they were significant.

sharing $=\beta 0+\beta 1$ app $+\beta 2$ eve $+\beta 3$ fan $+\beta 4$ inf $+\beta 5$ poo $+\beta 6 p p+\beta 7 b r 2+\beta 8 b r 3+\beta 9 b r 4+$ $\beta 10 \mathrm{br} 5+\beta 11 \mathrm{br} 6+\beta 12 \mathrm{br} 7+\beta 13 \mathrm{br} 8+\beta 14 \mathrm{dur}$ $+\beta 15$ qua $+\beta 16$ mor $+\beta 17$ evn $+\beta 18$ wee $+\beta 19$ jan $+\beta 20 \mathrm{fev}+\mathrm{u}(1)$

Assumption tests were carried out before choosing the analytical model. First, tests were done to identify the presence of heteroskedasticity. In both cases, the null hypothesis was rejected for the presence of constant variance of residuals. The White (1980) test returned a Chi value of 57.53 (p $<0.01$ ), while the Breusch and Pagan (1979) test returned a Chi value of $3803.95(\mathrm{p}<0.01)$. The normality of the residuals test $(\mathrm{Chi}=23758.9, \mathrm{p}$ $<0.01$ ) corroborates these results which show that the residuals do not have normal distribution. These procedures underlay the choice of a robust estimation model, using Generalized Least Squares (GLS). 


\section{Results}

Table 4 summarizes the descriptive statistics. We chose not to present the statistics for the control variables related to the brands (br1 through br8) because they were omitted in the sample. A post receives, on average, 1924.54 shares, with a standard deviation of 4712.65 . Of the qualitative independent variables used, the greatest number of posts was categorized in the Publicity and Promotion type (1801), about $69 \%$ of all the contents analyzed in the study. This implies that, in general, brands use Facebook to promote content on entertainment and to advertise draws and contests. Next comes the posts produced by fans (294), followed by those which communicate events related to the brands (191). The least used contents are those which advertise surveys (22) and applications (23), respectively.
In the case for post typology, Table 4 presents descriptive statistics of shares weighted by the number of posts inside each category.

The results of both quantitative control variables show that the average exposure time of publications was 61.57 days. This number is a direct function of the period over which the investigation extended, namely, three months, and showed a deviation of 25.44 . The quantity (qua) variable indicates that, on average, the brands make 4.72 posts per day, with a standard deviation of 2.83. The qualitative control variables indicate that the majority of posts $(1115,43 \%)$ occur in the afternoon, between 12:00 am and 5:59 pm, and midweek $(1509,58 \%)$. These results are important because they represent an indication of the activity of brands in the virtual social network. Further details on the relationship among control variables are expressed on the correlation matrix.

Table 4

Descriptive statistics

\begin{tabular}{lccc}
\hline Variable & Mean & Std. err. & Freq \\
\hline Dependent variable & & & \\
sharing & 1924.54 & 4712.65 & 2583 \\
\hline
\end{tabular}

\section{Independent variables ${ }^{a}$}

\begin{tabular}{lccc} 
app & 331.91 & 332.58 & 23 \\
eve & 363.56 & 832.09 & 191 \\
fan & 3352.91 & 4978.63 & 294 \\
inf & 419.44 & 987.68 & 168 \\
poo & 0.45 & 0.21 & 22 \\
pp & 2084.98 & 5160.45 & 1801 \\
ser & 985.03 & 1316.34 & 84 \\
\hline
\end{tabular}

Control variables

\begin{tabular}{lccc} 
dur & 61.57 & 25.44 & 2583 \\
qua & 4.72 & 2.83 & 2583 \\
mor & 0.32 & 0.46 & 848 \\
aft & 0.43 & 0.49 & 1115 \\
evn & 0.24 & 0.42 & 620 \\
mid & 0.58 & 0.49 & 1509 \\
wee & 0.41 & 0.49 & 1074 \\
dec & 0.34 & 0.47 & 879 \\
jan & 0.32 & 0.46 & 850 \\
feb & 0.33 & 0.47 & 854 \\
\hline
\end{tabular}

Note. ${ }^{a}$ Table 4 presents descriptive statistics of shares weighted by the number of posts inside each category. Grand mean in this case is unconditional sharing mean (1924.54) 
Table 5 presents inferential statistics and shows that the model adjusts adequately to the data. The variables included explain $16 \%$ of the variability in the shares of posts. Although low, which makes predictive structures less accurate, it explains more than the likes model of De Vries et al. (2012), for example. It is important to remember, however, that these two studies have slightly different goals. The value of R-squared and the use of variables is sustained by the overall significance of the regression which returned a F-statistic of 31.24 ( $\mathrm{p}<0.01)$. The constant is not significant because the authors decided on a grouping of reference variables which would give an intercept which would not be statistically significant. This procedure ensures that the marginal effect of the post types can be identified. It is important to mention that the tests for variance inflation factors (VIF) identified a weak presence of multicollinearity between the independent variables. Only the Promotion and Publicity (VIF $=7.21)$ variable presented a result close to 8 . Numbers greater than 10 could mean a problem of collinearity. However, the values varied between 1 and 5 with data from beer posts, which denotes an acceptable collinearity among the regressors (Gujarati \& Porter, 2008).

The results of the estimates for the control variables show that an effect of a major brand really exists. Of the eight brands chosen to control this effect, statistical significance was observed in six, which had positive (br2, br3, br4 and br8) or negative (br5 and br7) coefficients. These results show that the activity of a brand on Facebook may reflect the market share of this brand. However, it would be necessary to confront and compare these data, which was not possible in this study. In relation to the control variables, it was also seen that, on average, the morning period posts receive more shares than evening or night periods and similarly posts published in December received more shares than those of January or February.
All these coefficients were statistically significant at a $99 \%$ level, with the exception of the duration of the post (dur): the exposure time reduced the number of shares at a $90 \%$ confidence level.

\section{I Results of hypothesis tests}

As already mentioned, the analysis of the Constant (Const.) shows an intercept which is not statistically significant. That means that there is no relationship between the Service (ser) type and the number of shares. This category is omitted from Table 5 because it is the reference category of the type variables which is reproduced in the intercept. In statistical terms, its effect on viral marketing is zero and with that result one can say that there was no support for Hypothesis 7. Although there is consistent literature on the impact of additional elements and dimensions of services at individual and organizational levels (Raja et al., 2013), this effect is not reproduced in the virtual social networks. Posts that refer to Services, such as virtual store or customer service, do not influence the share of this post. It can even be affirmed that the values of br1, aft, mid and dec variables, all reproduced in the intercept, are also statistically equal to zero and do not have any linear impacts on the dependent variable.

Hypothesis 1 was not supported either, since the Application (app) type posts do not have a positive effect on the dependent variable. The use of applications increases user engagement and improves the reviews of users (Claussen et al., 2013) when the software developer is trusted (Eling et al., 2013). Although applications are crucial mechanisms for the dissemination of content (Eling et al., 2013), their use in brand posts does not have a significant impact on post sharing. Hypothesis 2 was not supported either because the coefficient of the variable Event (eve) is statistically equal to zero. The event pages on Facebook could even encourage individuals to participate in such events outside the social 
network (Lee \& Paris, 2013), although they do not directly lead to post sharing which mentions a certain event, when this content is published on brand profiles.

There was a positive and statistically significant effect at a $99 \%$ confidence level of the category Fan (fan) on sharing. This result guarantees confirmation of Hypothesis 3 and is the first evidence of viral marketing on Facebook. Many studies focus on the impact of usergenerated content on economic consequences, such as sales. The literature shows a positive effect on the aggregate sales of products such as films, books and video games (Goh et al., 2013). Our study provides a consistent analytical basis for the fact that posts classified in this category also have a positive impact on non-economic consequences, such as shares, a phenomenon which occurs in virtual social networks such as Facebook. This impact is important because the main objectives of a viral marketing campaign are to disseminate information, create awareness and cultivate brand perceptions (Hinz et al., 2011).

Consumers seek information about brands and in certain cases this search can be both time and effort-consuming (Kiel \& Layton, 1981). Unlike what is observed at individual level and outside the virtual context, providing information about brands in virtual social networks does not guarantee a response in non-economic measures. In our study, brand posts classified as Information (inf) did not have any positive effects on shares. These results do not support Hypothesis 4 and confirm the results of the study by De Vries et al. (2012) and Cvijikj and Michaehelles (2013) in which the authors, respectively, found no relationship between informative content, likes, comments and shares and concluded that this is not the characteristic which determines the popularity of a post.

Traditionally, marketing managers used the one-to-many communication format to disseminate brand values to the target public, but the advent of virtual social networks obliged them to incorporate this media into the communication mix (Gensler, Völckner, Liu-Thompkins, \& Wiertz, 2013). In one-to-many communication formats, there is a relationship between an individual and a mediator environment which provides high levels of interactivity (Hoffman \& Novak, 1996) as for example, through surveys. De Vries et al. (2012) found a negative relationship between high levels of interactivity and likes, and a positive relationship between high levels and comments. When specifically addressing the context of viral marketing, there were no positive effects of the Pool (poo) type of post on sharing, which do not support Hypothesis 5 in our study.

The second indication of viral marketing on Facebook stems from the positive effect of the Promotion and Publicity (pp) category. This effect supports Hypothesis 6 and shows that for posts which advertise contests and draws, and promote a brand with entertaining content there is an average increase of 2419.25 shares. This relationship is statistically significant at a 99\% level and corroborates the studies of Taylor et al. (2012) on Facebook, and Lin and Peña (2011) on Twitter. The former showed that entertainment content in advertisements in the virtual social network exerts a positive influence on the attitude of service users, while the latter showed that brands use positive tones in the management of socio-emotional communication with their audiences. Interestingly, the results of this type were different from those found in the De Vries et al. (2012) research, which did not find any significant relationship between posts with content referring to entertainment and likes and comments. Conversely, Cvijikj and Michaehelles (2013) found a significant and positive relationship between entertainment posts and likes, comments and shares. These results indicate the need for further research about post typology on virtual social networks. 
Table 5

Results for the independent and control variables coefficients

\begin{tabular}{|c|c|c|c|}
\hline Variable & B & SE & $p$-value \\
\hline Const. & -322.71 & 49.25 & 0.51 \\
\hline \multicolumn{4}{|c|}{ Independent variables } \\
\hline app & -179.90 & 327.36 & 0.58 \\
\hline eve & -162.24 & 326.49 & 0.61 \\
\hline fan & 2226.59 & 382.23 & 0.00 \\
\hline $\inf$ & 115.64 & 281.44 & 0.68 \\
\hline poo & 667.78 & 448.13 & 0.13 \\
\hline $\mathrm{pp}$ & 2418.25 & 295.99 & 0.00 \\
\hline \multicolumn{4}{|c|}{ Control variables } \\
\hline br2 & 2086.40 & 314.52 & 0.00 \\
\hline br3 & 1616 & 265.85 & 0.00 \\
\hline br4 & 1160.84 & 276.70 & 0.00 \\
\hline br5 & -790.64 & 225.16 & 0.00 \\
\hline br6 & -280.95 & 244.22 & 0.25 \\
\hline br7 & -648.86 & 227.89 & 0.00 \\
\hline br8 & 4718.05 & 555.87 & 0.00 \\
\hline dur & -10.87 & 6.12 & 0.07 \\
\hline qua & -64.13 & 46.67 & 0.16 \\
\hline mor & 589.61 & 204.58 & 0.00 \\
\hline evn & 38.64 & 228.75 & 0.86 \\
\hline wee & 151.78 & 187.64 & 0.41 \\
\hline jan & -730.67 & 242.77 & 0.00 \\
\hline feb & -986.72 & 293.65 & 0.00 \\
\hline
\end{tabular}

Goodness of fit

Adjust R-square: 0.16

$\mathrm{F}=31.24, \mathrm{p}<0.01$

Note. Figures in bold: $p$-value $<0.00$; in italic: $p$-value $<0.10$.

\subsection{Additional analysis}

We concentrated on Fan and Promotion and Publicity typologies to conduct additional analysis on our results. The objective was to explore the results found in our inferential model. At first, we performed simple independent samples $T$ tests to compare means of these two groups, considering the whole set of control variables. Considering the postings of the eight brands on the dataset and post quantity per day, means where statistically different at a 99\% level. For time of the day, means where different at a 99\% (for morning), 95\% (afternoon) and 90\% (evening) levels. The results suggest no statistical difference in means for post duration, time of the week and month. Table 6 summarizes the results of the $\mathrm{T}$ tests.

A second procedure involved an ANOVA in order to meet two objectives: first, to generate estimated marginal means and, second, to identify the partial effect for each post typology. In this model, we used sharing as dependent variable and post typologies as factor variables. We have tried to run an ANCOVA using post quantity and duration as covariates, but basic assumptions of this model (independence of the covariate and treatment effect and homogeneity of regression slopes) were violated (Field, 2009). Figure 2 reveals the first output from the ANOVA, indicating that Fan and Promotion and Publicity posts are indeed way above from the baseline, both 
generating more than at least 2000 shares, while Application, Event, Information and Pool are near the point marked at zero. Postings categorized as Service are only slightly above this baseline.

Table 6

Results for $\mathbf{T}$ tests using two groups: fan and promotion and publicity typologies

\begin{tabular}{ccccc}
\hline Variable & $\begin{array}{c}\text { Equal variances } \\
\text { assumed? }\end{array}$ & $\boldsymbol{t}$ value & $\boldsymbol{p}$-value & Mean difference \\
\hline dur & yes & -.49 & .62 & -.80 \\
qua & no & 8.47 & $\mathbf{. 0 0}$ & 1.11 \\
mor & no & -6.03 & $\mathbf{. 0 0}$ & -.15 \\
aft & no & 3.49 & .00 & .10 \\
eve & no & 1.76 & .07 & .04 \\
mid & yes & .73 & .46 & .02 \\
wee & yes & -.73 & .46 & -.02 \\
dec & yes & -.82 & .40 & -.02 \\
jan & yes & .86 & .38 & .02 \\
feb & no & -.01 & .98 & -.00 \\
\hline
\end{tabular}

Note. Figures in bold: $p$-value $<0.001$; in bold and italic: $p$-value $<0.05$; in italic: $p$-value $<0.10$

${ }^{a}$ Provided by Levene's hypothesis test for equality of variances (We used a $95 \%$ confidence level for this test)

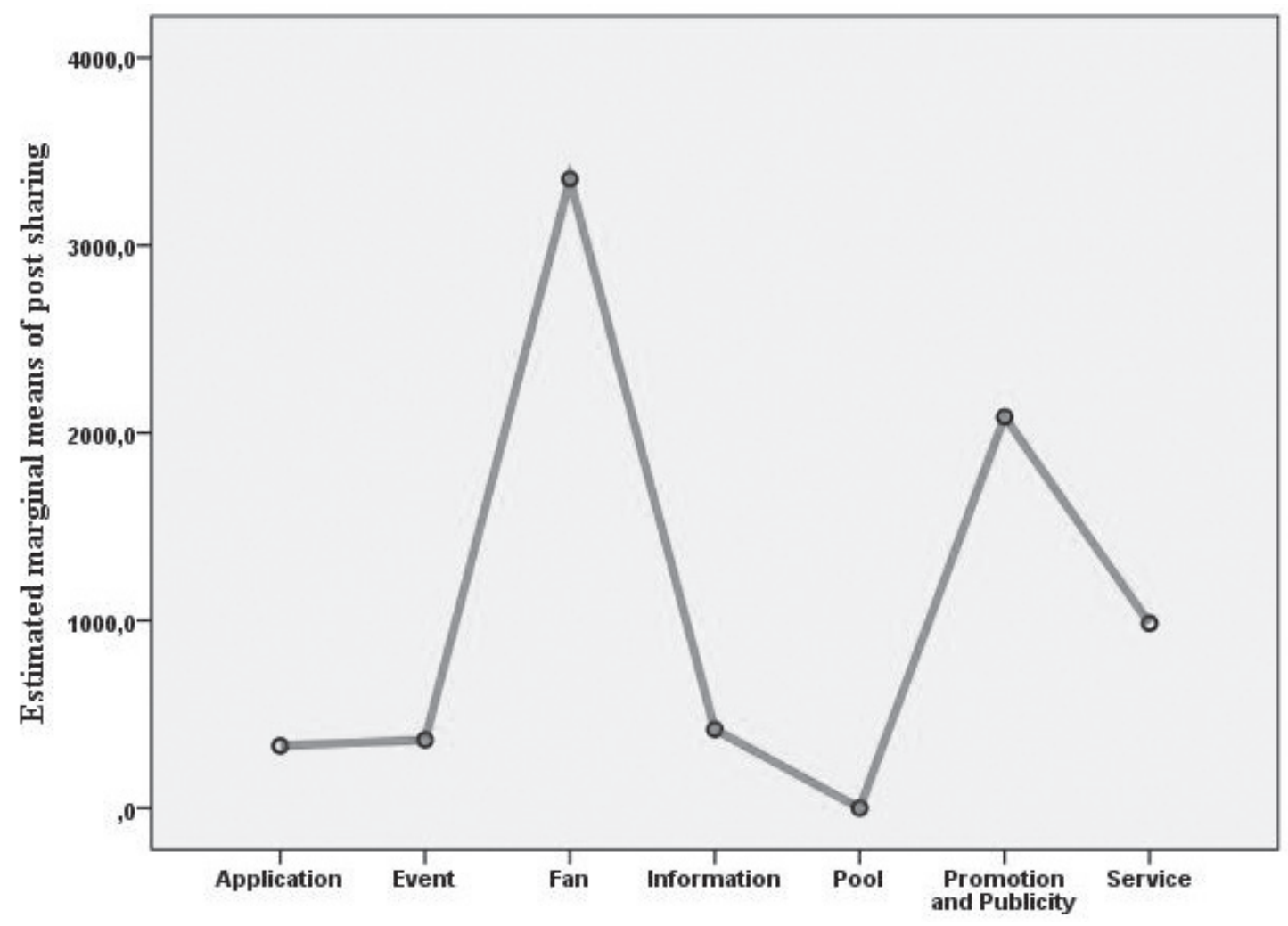

Figure 2. Estimated marginal means considering different post typologies 
Table 7 complements Figure 2 and presents the results from the ANOVA model. It reveals that only coefficients from Fan and Promotion and Publicity typologies are statistically different from Service, the reference category. Fan is significant at a 99\% level, while Promotion and Publicity, at a 95\% level. Partial effects from the first typology is three times higher than the latter, clearly indicating a patch of how marketers should invest on content categorization on Facebook, in order to enhance the likelihood of viral marketing.

Table 7

\section{Parameter estimates for the ANOVA model}

\begin{tabular}{lcccc}
\hline Parameter & B & t value & p-value & Partial Eta Squared \\
\hline Intercept & 985.03 & 1.94 & .05 & .001 \\
Application & -653.12 & -.59 & .55 & .000 \\
Event & -621.47 & -1.02 & .30 & .000 \\
Fan & 2367.87 & 4.11 & .00 & .007 \\
Information & -565.58 & 621.03 & .36 & .000 \\
Pool & -984.99 & -.885 & .37 & .000 \\
Promotion and Publicity & 1099.94 & 2.12 & .03 & .002 \\
Service & $0^{\mathrm{a}}$ & & & \\
\hline
\end{tabular}

Note. Figures in bold: $p$-value $<0.001$; in bold and italic: $p$-value $<0.05$

a This parameter is set to zero because it is redundant (reference category)

\section{Discussion and managerial implications}

Virtual social networks like Facebook have revolutionized the ways how organizations relate to their markets and to society in general, and have created a world of new possibilities and challenges for various aspects of the company (Aral, Dellarocas, \& Godes, 2013). As these media gain popularity among users, managers seek ways to include these networks in marketing strategy in order to engage and influence their target audiences (Hoffman \& Novak, 2012). These networks lead to the active participation of the individual and guarantee high levels of network interconnectivity (Hennig-Thurau, Hofacker, \& Bloching, 2013) which transform key aspects of marketing and consumer behavior. However, despite such progress, many questions remain unanswered (Aral et al., 2013) and researchers still study more effective metrics for managing brands in these environments (Peters et al., 2013).

One of the best known response mechanisms on Facebook is the option of sharing.
People who access virtual social networks can produce and modify content, but above all, they have the option of sharing it (Peters et al., 2013). Kietzmann et al. (2012) mention one major implication of sharing in virtual social networks: the need to discover what forces induce people to disseminate such content. This need is supported by theoretical gaps seen in the literature on viral marketing. Bampo, Ewing, Mather, Stewart and Wallace (2008), for example, show the need for intensified analysis of managerial interference in viral marketing on Facebook while Schulze et al. (2014) highlights differences on sharing mechanisms for utilitarian and low-utilitarian products, such as games and music services.

Our study contributes to the current research on viral marketing by analyzing the impact of brand content in virtual social networks. First, our typology, based on the building of seven categories of post, is a quantitative improvement in relation to studies with similar objectives, as it includes a more comprehensive and extensive number of contents in interactions between brand and target audiences. Secondly, the results of the 
hypotheses tests, summarized in Table 8 show the importance of user-generated content and that which mention offers or promotes the brand on the social network. Previous studies using Facebook platform did not categorize posts created by brand fans/followers. The main managerial implications refer to these two categories, which showed linear and positive impacts on the number of shares: marketers engaged in brand management on Facebook should publish posts which promote the brand and reproduce content generated by people engaged with the brand if they are to increase the viralization capacity of such posts.

\section{Table 8}

\section{Results of hypothesis testing}

\begin{tabular}{|c|c|c|c|c|}
\hline Hypothesis & Post typology & Expected signal & Impact & Interpretation \\
\hline 1 & Application & Positive & None & Not supported \\
\hline 2 & Event & Positive & None & Not supported \\
\hline 3 & Fan & Positive & Positive & Supported \\
\hline 4 & Information & Positive & None & Not supported \\
\hline 5 & Pool & Positive & None & Not supported \\
\hline 6 & Promotion and Publicity & Positive & Positive & Supported \\
\hline 7 & Service & Positive & None & Not supported \\
\hline
\end{tabular}

\section{Limitations and future research}

The main limitation of this study is related to the reduced number of samples in some categories. Pool (22) and Application (23) come close to one percent of posts analyzed. As they are less frequent, a study which would increase their number would require more time during the data collection phase. Another major consideration which limits the scope of our study is the inclusion of many control variables of a qualitative nature. Further studies should incorporate, for example, the length of the message in characters and try to consolidate all the variables used in earlier studies. Finally, the Least Squares method limits the analysis to a linear function. New methods could improve the explanatory power of viral marketing on Facebook.

Future studies should extend and improve the presented model. Firstly, it would be appropriate to test the share variable in logarithmic form in order to analyze the rate of variation of viral marketing, as previous studies did. Nevertheless, to make that feasible, it is suggested that a time restriction should be included in order to analyze the evolution of this rate over time. Secondly, new models could include other non-economic response variables, such as likes and comments, and consider the endogeneity of variables such as likes, comments and shares. The empirical structure would be grounded on systems of equations which, theoretically, seem to better capture the dynamics of interaction between individuals and brands on Facebook, as those who enjoy a particular post seem to be more inclined to comment on and share it.

\section{References}

Abram, C., \& Pearlman, L. (2008). Facebook for dummies. Hoboken, NJ: John Wiley \& Sons.

Ahrens, J., Coyle, J. R., \& Strahilevitz, M. A. (2013). Electronic word of mouth: The effects of incentives on e-referrals by senders and receivers. European Journal of Marketing, 47(7), 1034-1051.

Aral, S., Dellarocas, D., \& Godes, D. (2013). Social media and business transformation: A framework for research. Information Systems Research, 24(1), 3-13.

Aral, S., \& Walker, D. (2011). Creating social contagion through viral product design: A randomized trial of peer influence in networks. Management Science, 57(9), 1623-1639. 
Azar, S. L., Machado, J. C., Vacas-de-Carvalho, L., \& Mendes, A. (2016). Motivations to interact with brands on Facebook: Towards a typology of consumer-brand interactions. Journal of Brand Management, 23(2), 157-178.

Bagozzi, R. P. (1998). Marketing management. Upper Saddle River, NJ: Prentice-Hall.

Bampo, M., Ewing, M. T., Mather, D. R., Stewart, D., \& Wallace, M. (2008). The effects of the social structure of digital networks on viral marketing performance. Information Systems Research, 19(3), 237-290.

Boyd, D. M., \& Ellison, N. B. (2007). Social network sites: Definition, history, and scholarship. Journal of Computer-Mediated Communication, 13(1), 210-230.

Breusch, T. S., \& Pagan, A. R. (1979). A simple test for heteroscedasticity and random coefficient variation. Econometrica, 47(5), 1287-1294.

Brodie, R. J., Hollebeek, L. D., Jurić, B., \& Ilić, A. (2011). Customer engagement: Conceptual domain, fundamental propositions, and implications for research. Journal of Service Research, 14(3), 252-271.

Camarero, C., \& San José, R. (2011). Social and attitudinal determinants of viral marketing dynamics. Computers in Human Behavior, 27(6), 2292-2300.

Chan, Y. Y. Y., \& Ngai, C. E. W. T. (2011). Conceptualising electronic word of mouth activity. Marketing Intelligence \& Planning, 29(5), 488-516.

Chevalier, J. A., \& Mayzlin, D. (2006). The effect of word of mouth on sales: Online book reviews. Journal of Marketing Reserach, 43(3), 345-354.

Chu, S., \& Kim, Y. (2011). Determinants of consumer engagement in electronic word-of- mouth (eWOM) in social networking sites. International Journal of Advertising, 30(1), 47-75.

Claussen, J., Kretschmer, T., \& Mayrhofer, P. (2013). The effects of rewarding user engagement: The case of Facebook apps. Information Systems Research, 24(1), 186-200.

Cvijikj, I. P., \& Michahelles, F. (2013). Online engagement factors on Facebook brand pages. Social Network Analysis and Mining, 3(4), 843-861.

De Bruyn, A., \& Lilien, G. L. (2008). A multistage model of word-of-mouth influence through viral marketing. International Journal of Research in Marketing, 25(3), 151-163.

De Vries, L., Gensler, S., \& Leeflang, P. S. H. (2012). Popularity of brand posts on brand fan pages: An investigation of the effects of social media marketing. Journal of Interactive Marketing, 26(2), 83-91.

Dessart, L., Veloutsou, C., \& Morgan-Thomas, A. (2015). Consumer engagement in online brand communities: A social media perspective. Journal of Product \& Brand Management, 24(1), 28-42.

Dholakia, U. M., Bagozzi, R. P., \& Pearo, L. K. (2004). A social influence model of consumer participation in network and small-group-based virtual communities. International Journal of Research in Marketing, 21(3), 241-263.

Duan, W., Gu, B., \& Whinston, A. B. (2008). The dynamics of online word-of-mouth and product sales: An empirical investigation of the movie industry. Journal of Retailing, 84(2), 233-242.

Eckler, P., \& Bolls, P. (2011). Spreading the virus emotional tone of viral advertising and its effect on forwarding intentions and attitudes. Journal of Interactive Advertising, 11(2), 1-11.

Eisend, M., \& Küster, F. (2011). The effectiveness of publicity versus advertising: A meta-analytic 
investigation of its moderators. Journal of the Academy of Marketing Science, 39(6), 906-921.

Eling, N., Krasnova, H., Widjaja, T., \& Buxmann, P. (2013). Will you accept an app? Empirical investigation of the decisional calculus behind the adoption of applications on Facebook. Proceedings of the International Conference of Information Systems, Milan, Italy.

Erdogmus, I. E., \& Çiçek, M. (2012). The impact of social media marketing on brand loyalty. Procedia - Social and Behavioral Sciences, 58, 1353-1360.

Facebook. (2014). Facebook newsroom: Company info. Retrieved from http://newsroom.fb.com/ company-info/

Fennis, B. M., \& Stroebe, W. (2010). The psychology of advertising. New York, NY: Psychology Press.

Field, A. (2009). Discovering statistics using SPSS. Thousand Oaks, CA: Sage Publications.

Fortin, D. R., \& Dholakia, R. R. (2005). Interactivity and vividness effects on social presence and involvement with a web-based advertisement. Journal of Business Research, 58(3), 387-396.

Furrer, O., Thomas, H., \& Goussevskaia, A. (2008). The structure and evolution of the strategic management field: A content analysis of 26 years of strategic management research. International Journal of Management Reviews, 10(3), 1-23.

Gensler, S., Völckner, F., Liu-Thompkins, T., \& Wiertz, C. (2013). Managing brands in the social media environment. Journal of Interactive Marketing, 27(4), 242-256.

Goh, K., Heng, C., \& Lin, Z. (2013). Social media brand community and consumer behavior: Quantifying the relative impact of user- and marketer-generated content. Information Systems Research, 24(1), 88-107.

Groeger, L., \& Buttle, F. (2014). Word-of-mouth marketing: Towards an improved understanding of multi-generational campaign reach. European Journal of Marketing, 48(7/8), 11860-1208.

Gujarati, D., \& Porter, D. (2008). Basic econometrics. New York, NY: McGraw-Hill.

Harvey, C. G., Stewart, D. B., \& Ewing, M. T. (2011). Forward or delete: What drives peer-topeer message propagation acrosss social networks? Journal of Consumer Behavior, 10(6), 365-372.

Heerde, H. J., \& Neslin, S. A. (2008). Sales promotion models. In B. Wierenga (Ed.). Handbook of marketing decision models (107-162). New York, NY: Springer.

Hennig-Thurau, T., Malthouse, E. C., Friege, C., Gensler, S., Lobschat, L., Rangaswamy, A., \& Skiera, B. (2010). The impact of new media on customer relationships. Journal of Service Research, 13(3), 311-330.

Hennig-Thurau, T., Gwinner, K. P., Walsh, G., \& Gremler, D. D. (2004). Electronic word-ofmouth via consumer-opinion platforms: What motivates consumers to articulate themselves on the Internet? Journal of Interactive Marketing, 18(1), 38-52.

Hennig-Thurau, T., Hofacker, C. F., \& Bloching, B. (2013). Marketing the pinball way: Understanding how social media change the generation of value for consumer and companies. Journal of Interactive Marketing, 27(4), 237-241.

Hinz, O., Skiera, B., Barrot, C., \& Becker, J. U. (2011). Seeding strategies for viral marketing: An empirical comparison. Journal of Marketing, 75(6), 55-71.

Ho, J. Y. C., \& Dempsey, M. (2010). Viral marketing: Motivations to forward online 
content. Journal of Business Research, 63(9), 10001006.

Hoffman, D. L., \& Fodor, M. (2010). Can you measure the ROI of your social media marketing? MIT Sloan Management Review, 52(1), 41-49.

Hoffman, D. L., \& Novak, T. P. (1996). Marketing in hypermidia computer-mediated environments: Conceptual foundations. Journal of Marketing, 60(3), 50-68.

Hoffman, D. L., \& Novak, T. P. (2012). Toward a deeper understanding of social media. Journal of Interactive Marketing, 26(2), 67-70.

Hollebeek, L. D., Glynn, M. S., \& Brodie, R. J. (2014). Consumer brand engagement in social media: Conceptualization, scale development and validation. Journal of Interactive Marketing, 28(2), 149-165.

Hoy, M. G., \& Milne, G. (2010). Gender differences in privacy-related measures for young adult Facebook users. Journal of Interactive Advertising, 10(2), 28-45.

Iribarren, J. L., \& Moro, E. (2011). Branching dynamics of viral information spreading. Physical Review E, 84(4), 046116.

Jansen, B., Zhang, M., Sobel, K., \& Chowdury, A. (2009). Twitter power: Tweets as electronic word of mouth. Journal of the American Society for Information Science and Technology, 6O(11), 2169-2188.

Jurvetson, S. \& Draper, T. (1997). Viral marketing: Viral marketing phenomenon explained. Retrieved from http:/www.df.com/news/article_26.shtml/

Kaplan, A. M., \& Haenlein, M. (2010). Users of the world, unite! The challenges and opportunities of social media. Business Horizons, 53(1), 59-68.

Kiel, G. C., \& Layton, A. (1981). Dimensions of consumer information seeking behavior. Journal of Marketing Research, 18(2), 233-239.

Kietzmann, J. H., Silvestre, B. S., \& McCarthy, I. P. (2012). Unpacking the social media phenomenon: Towards a research agenda. Journal of Public Affairs, 12(9), 109-119.

Kim, D., Spiller, L., \& Hettche, M. (2015). Analyzing media types and content orientations in Facebook for global brands. Journal of Research in Interactive Marketing, 9(1), 4-30.

Kumar, V., Bhaskaran, V., Mirchandani, R., \& Shah, M. (2013). Creating a mensurable social media marketing strategy: Increasing the value and ROI of intangibles and tangibles for Hokey Pokey. Marketing Science, 32(2), 194-212.

Kumar, V., \& Mirchandani, R. (2012). Increasing the ROI of social media marketing. MIT Sloan Management Review, 54(1), 55-61.

Lee, W., \& Paris, C. M. (2013). Knowledge sharing and social technology acceptance model: Promoting local events and festivals through Facebook. Tourism Analysis, 18(4), 457-469.

Lee, W., Xiong, L., \& Hu, C. (2012). The effect of Facebook users' arousal and valence on intention to go to the festival: Applying and extension of the technology acceptance model. International Journal of Hospitality Management, 31(3), 819-827.

Leskovec, J., Adamic, L. A., \& Huberman, B. A. (2007). The dynamics of viral marketing. ACM Transactions on the Web, 1(1), 1-46.

Lin, K.-Y., \& Lu, H.-P. (2011). Why people use social networking sites: An empirical study integrating network externalities and motivation theory. Computers in Human Behavior, 27(3), 1152-1161.

Lin, J. S., \& Peña, J. (2011). Are you following me? A content analysis of TV networks brand communication on Twitter. Journal of Interactive Advertising, 12(1), 17-29. 
Lindgreen, A., Doeble, A., \& Vanhamme, J. (2013). Word-of-mouth and viral marketing referrals: What do we know? European Journal of Marketing, 47(7), 1028-1033.

Martensen, A., \& Gronholdt, L. (2008). How events work: Understanding consumer responses to event marketing. Innovative Marketing, 4(4), 44-56.

Modzelewski, F. M. (2000). Finding a cure for viral marketing. Direct Marketing News, $11(9)$.

Nelson-Field, K., Riebe, E., \& Newstead, K. (2013). The emotions that drive viral video. Australasian Marketing Journal, 21(4), 205-211.

Oeldorf-Hirsch, A., \& Sundar, S. S. (2015). Posting, commenting, and tagging: Effects of sharing news stories on Facebook. Computers in Human Behavior, 44, 240-249.

Oh, S., \& Syn, S. Y. (2015). Motivations for sharing information and social support in social media: A comparative analysis of Facebook, Twitter, Delicious, YouTube, and Flickr. Journal of the Association for Information Science and Technology, 66(10), 2045-2060.

Park, N., Kee, K. F., \& Valenzuela, S. (2009). Being immersed in social networking environment: Facebook groups, uses and gratifications, and social outcomes. CyberPsychology \& Behavior, 12(6), 729-733.

Park, M., \& Lennon, S. J. (2009). Brand name and promotion in online shopping contexts. Journal of Fashion Marketing and Management, 13(2), 149-160.

Pavlou, P. A., \& Dimoka, A. (2006). The nature and role of feedback text comments in online marketplaces: Implications for trust building, price premiums, and seller differentiation. Information Systems Research, 17(4), 392-414.
Peters, K., Chen, Y., Kaplan, A. M., Ognibeni, B., \& Pauwels, K. (2013). Social media metrics: A framework and guidelines for managing social media. Journal of Interactive Marketing, 27(4), 281-298.

Porter, L., \& Golan, G. J. (2006). From subservient chicken to brawny men: A comparison of viral advertising to television advertising. Journal of Interactive Advertising, 6(2), 26-33.

Raja, J. Z., Bourne, D., Goffin, K., Çakkol, M., \& Martinez, V. (2013). Achieving customer satisfaction through integrated products and services: An exploratiory study. Journal of Product Innovation Management, 30(6), 1128-1144.

Ransbotham, S., Kane, G. C., \& Lurie, N. H. (2012). Network characteristics and the value of collaborative user-generated content. Marketing Science, 31(3), 387-405.

Rauschnabel, P. A., Praxmarer, S., \& Ivens, B. S. (2012). Social media marketing: How design features influence interactions with brand postings on Facebook. In M. Eisend, T. Langner, \& S. Okazaki (Eds.). Advances in Advertising Research (Vol. III). Wiesbaden, Germany: Springer Gabler.

Rohm, A., Kaltcheva, V. D., \& Milne, G. R. (2013). A mixed-method approach to examining brand-consumer interactions driven by social media. Journal of Research in Interactive Marketing, 7(4), 295-311.

Russell-Bennet, R., \& Neale, L. (2009). Social networking: Investigating the features of Facebook application. Proceedings of Academy of Marketing Annual Conference, United Kingdom.

Sabate, F., Berbegal-Mirabent, J., Cañabate, A., \& Lebherz, P. (2014). Factors influencing popularity of branded content in Facebook. European Management Journal, 32(6), 1001-1011. 
Schultz, D. E., \& Peltier, J. (2013). Social media’s slippery slope: Challenges, opportunities and future research directions. Journal of Research in Interactive Marketing, 7(2), 86-99.

Schulze, C., Schöler, L., \& Skiera, B. (2014). Not all fun and games: Viral marketing for utilitarian products. Journal of Marketing, 78(1), 1-19.

Smith, A. N., Fischer, E., \& Yongjian, C. (2012). How does brand-related user-generated content differ across Youtube, Facebook, and Twitter. Journal of Interactive Marketing, 26(2), 102-113.

Sohn, D. (2009). Disentangling the effects of social network density on electronic word-ofmouth (eWOM) intention. Journal of ComputerMediated Communication, 14(2), 352-367.

Southgate, D., Westoby, N., \& Page, G. (2010). Creative determinats of viral video viewing. International Journal of Advertising, 29(3), 349-368.

Stammerjohan, C., Wood, C. M., Chang, Y., \& Thorson, E. (2005). An empirical investigation of the interaction between publicity, advertising, and previous brand attitudes and knowledge. Journal of Advertising, 34(4), 55-67.

Sun, T., Youn, S., Wu, G., \& Kuntaraporn, M. (2006). Online word-of-mouth (or Mouse): An exploration of its antecedents and consequences. Journal of Computer-Mediated Communication, 11(4), 1104-1127.

Swanepoel, C., Lye, A., \& Rugimbana, R. (2009). Virally inspired: A review of the theory of viral stealth marketing. Australasian Marketing Journal, 17(1), 9-15.

Swani, K., Milne, G., \& Brown, B. P. (2013). Spreading the word through likes on Facebook. Journal of Research in Interactive Marketing, 7(4), 269-294.
Taylor, D. G., Lewin, J. E., \& Strutton, D. (2011). Friends, fans, and followers: Do ads work on social networks? Journal of Advertising Research, 51(1), 258-275.

Taylor, D. G., Strutton, D., \& Thompson, K. (2012). Self-enhancement as a motivation for sharing online advertising. Journal of Interactive Advertising, 12(2), 13-28.

Van der Lans, R., Van Bruggen, G., Eliashberg, J., \& Wierenga, B. (2010). A viral branching model for predicting the spread of electronic word of mouth. Marketing Science, 29(2), 348-365.

Vilpponen, A., Winter, A., \& Sundqvist, S. (2006). Electronic word-of-mouth in online environments: Exploring referral networks structure and adoption behavior. Journal of Interactive Advertising, 6(2), 8-77.

Wellman, B. (2001). Computer networks as social networks. Science, 293(5537), 2031-2034.

White, H. (1980). A heteroskedasticity-consistent covariance matrix estimator and a direct test for heteroskedasticity. Econometrica, 48(4), 817-838.

Wooldridge, J. M. (2013). Introductory econometrics: A modern approach. Mason, $\mathrm{OH}$ : Cengage Learning.

Yang, J., Yao, C., Ma, W., \& Chen, G. (2010). A study of the spreading scheme of viral marketing based on a complex network model. Physica $A$, 389(4), 859-870.

Zarrella, D., \& Zarrella, A. (2010). The Facebook marketing book. Sebastopol, CA: O'Reilly Media.

Zhang, L., Ma, B., \& Cartwright, D. K. (2013). The impact of online user reviews on câmera sales. European Journal of Marketing, 47(7), 1115-1128. 
About the authors:

1. Marcos Inácio Severo de Almeida, PhD in Management, University of Brasília (UNB), Brazil.

Email: misevero@yahoo.com.br

2. Milena Costa, Bachelor in Management, Federal University of Goiás (UFG), Brazil.

Email: milena_lumus@hotmail.com

3. Ricardo Limongi França Coelho, MSc in Management, Vale do Rio dos Sinos University (Unisinos),

Brazil. Email: ricardolimongi@gmail.com

4. Paulo Roberto Scalco, PhD in Applied Economics, Federal University of Viçosa (UFV), Brazil.

Email: pauloscalco@yahoo.com.br

Contribution of each author:

\begin{tabular}{|c|c|c|c|c|}
\hline Contribution & $\begin{array}{l}\text { Marcos I. S. } \\
\text { Almeida }\end{array}$ & $\begin{array}{c}\text { Milena } \\
\text { Costa }\end{array}$ & $\begin{array}{l}\text { Ricardo L. F. } \\
\text { Coelho }\end{array}$ & $\begin{array}{l}\text { Paulo R. } \\
\text { Scalco }\end{array}$ \\
\hline 1. Definition of research problem & $\sqrt{ }$ & $\sqrt{ }$ & & \\
\hline $\begin{array}{l}\text { 2. Development of hypotheses or research questions (empirical } \\
\text { studies) }\end{array}$ & $\sqrt{ }$ & $\sqrt{ }$ & $\sqrt{ }$ & $\sqrt{ }$ \\
\hline 3. Development of theoretical propositions (theoretical Work) & $\sqrt{ }$ & & & \\
\hline 4. Theoretical foundation/ Literature review & $\sqrt{ }$ & $\sqrt{ }$ & & \\
\hline 5. Definition of methodological procedures & $\sqrt{ }$ & & & $\sqrt{ }$ \\
\hline 6. Data collection & & $\sqrt{ }$ & & \\
\hline 7. Statistical analysis & $\sqrt{ }$ & & & $\sqrt{ }$ \\
\hline 8. Analysis and interpretation of data & $\sqrt{ }$ & & $\sqrt{ }$ & \\
\hline 9. Critical revision of the manuscript & $\sqrt{ }$ & & $\sqrt{ }$ & $\sqrt{ }$ \\
\hline 10. Manuscript Writing & $\sqrt{ }$ & $\sqrt{ }$ & & $\sqrt{ }$ \\
\hline
\end{tabular}

